\title{
COMPARATIVE ANALYSIS OF THE PSY-5 AND MCMI-III IN ASSESSING PERSONALITY DISORDERS
}

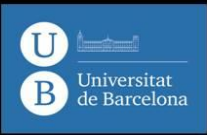

\author{
Fusté, A., Ruiz, J. \& García, E. \\ Department of Personality, Assessment and Psychological Treatments \\ University of Barcelona
}

\section{INTRODUCTION AND PURPOSE}

PARTICIPANTS

\begin{abstract}
According to Harkness and McNulty (1994) the Personality Psychopathology-Five (PSY-5) including in the MMPI-2-RF is a dimensional model developed to conceptualize the traits underlying personality psychopathology. Personality disorder-related diagnostic considerations listed by Ben-Porath \& Tellegen (2008) are, for the most part, inferential. Research with the PSY-5 scales has mainly focused on correlational data and comparisons between the scales and other selfreport instruments such as the NEO-PI-R, MPQ and SCL-90-R (Wygant, Sellbom, Graham and Schenk, 2006). However, we found no studies that have examined the relationship between PSY-5 scales and MCMI-III personality disorders scales. The present study examines the correspondence between PSY-5 scales and personality disorders based on the DSM-IVTR criteria and measured with MCMI-III Personality Disorder (PD) scales
\end{abstract}

\section{PROCEDURE}

The MCMIIII and MMPI-2-RF were administered to the clinical sample of 377 outpatients as part of their psychological assessment process.

Reliability estimates (Cronbach's alpha) in the present study ranged from 0.88 for $\mathrm{CC}$ to 0.65 for scale 7 for the MCMI-III and from 0.92 for $\mathrm{RCd}$ to 0.68 (AGGR and INTR scales) for the MMPI-2-RF.

The MMPI-2-RF scales used in this study were the five PSY-5 scales and personality disorders scales from MCMI-III.

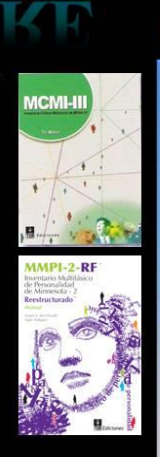

Regression analyses We performed several multiple regression analyses to determine which MCMT-III Pd scales contribute to explain the variance of each PSY-5 scales. To find the best regression model, we calculated all-possible-subset regression in
conjunction with stepwise methods and we selected the Adjusted R squared value as criterion to choosing the best subset of predictor effects. The percentage of variance of each of PSY-5 scales explained by MCMI-III PD scales ranged between $40 \%$ and $50.8 \%$. In general, results did not supported proposec hypothesis. For example, the MCMI-III Antisocial $\mathrm{Pd}$ scale did not contribute in the prediction of PSY5 AGGR scale. However, this one is more related to interpersonal characteristics, and it may not be directly related to antisocial personality, which is a more behavioral symptom constellation. (Wygant et al. 2006; Harkness et al., 2011). Also, the results confirm NEGER as a general marker psychopathology encompassing traits such as etc. Therefore, this scale is associated with several personality disorders but not from cluster

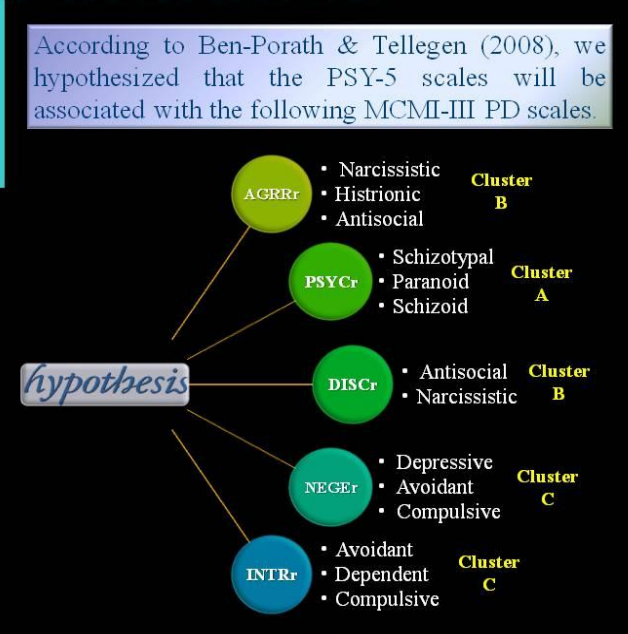

RESULTS

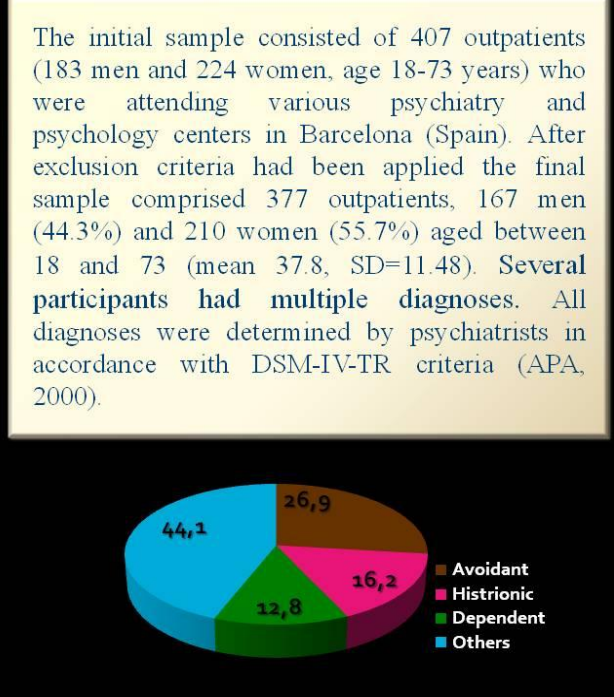

Correlational analyses

\begin{tabular}{|c|c|c|c|c|c|}
\hline \multicolumn{5}{|c|}{ Correlational analyses } & Correla \\
\hline \multicolumn{5}{|c|}{$\begin{array}{l}\text { We performed a zero-order correlations } \\
\text { between PSY-5 scales and MCMI-III } \\
\text { Personality Disorder scales. Given that the } \\
\text { significance of product moment } \\
\text { correlations is an effect size measure } \\
\text { (Meyer et al., 2008), the interpretation of } \\
\text { relationships was made not only on the } \\
\text { basis of statistical significance but also in } \\
\text { terms of their magnitude. We therefore } \\
\text { chose to emphasize only those } \\
\text { correlations that reached or exceeded a } \\
\text { large effect size }(r>0.50 \text {, Cohen, 1988). }\end{array}$} & $\begin{array}{l}\text { Schizoid } \\
\text { Avoidant } \\
\text { Depressive } \\
\text { Dependent } \\
\text { Histrionic } \\
\text { Narcissistic } \\
\text { Antisocial } \\
\text { Aggressive } \\
\text { Compulsive } \\
\text { Negativistic } \\
\text { Self-Defeatin } \\
\text { Schizotypal } \\
\text { Borderline } \\
\end{array}$ \\
\hline D.V. & I.D & $\beta$ & F & 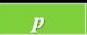 & Adjusted $\mathrm{R}^{2}$ \\
\hline $\begin{array}{l}\text { A } \\
\text { G } \\
\text { G } \\
\text { R }\end{array}$ & $\begin{array}{l}\text { Narcissistic } \\
\text { Dependent } \\
\text { Histrionic } \\
\text { Aggressive } \\
\text { Compulsive }\end{array}$ & $\begin{array}{c}0.39 \\
-0.26 \\
0.20 \\
0.20 \\
0.10\end{array}$ & $\begin{array}{l}44.76 \\
20.71 \\
8.74 \\
6.92 \\
4.36\end{array}$ & $\begin{array}{l}0.0000 \\
0.0000 \\
0.0033 \\
0.0089 \\
0.0375\end{array}$ & $\begin{array}{c}0.445 \\
p=0.000\end{array}$ \\
\hline & $\begin{array}{l}\text { Schizotypal } \\
\text { Paranoid } \\
\text { Avoidant } \\
\text { Borderline }\end{array}$ & $\begin{array}{c}0.43 \\
0.25 \\
-0.18 \\
0.18\end{array}$ & $\begin{array}{c}31.99 \\
18.57 \\
5.24 \\
8.27\end{array}$ & $\begin{array}{l}0.0000 \\
0.0000 \\
0.0226 \\
0.0043\end{array}$ & $\begin{array}{c}0.489 \\
p=0.000\end{array}$ \\
\hline $\begin{array}{l}\text { D } \\
\text { I } \\
\text { S }\end{array}$ & $\begin{array}{l}\text { Antisocial } \\
\text { Narcissistic } \\
\text { Schizoid }\end{array}$ & $\begin{array}{r}0.63 \\
0.15 \\
-0.11\end{array}$ & $\begin{array}{c}103.46 \\
8.41 \\
3.90\end{array}$ & $\begin{array}{l}0.0000 \\
0.0040 \\
0.0490\end{array}$ & $\begin{array}{c}0.400 \\
p=0.000\end{array}$ \\
\hline $\begin{array}{l}\mathbf{G} \\
\mathbf{E}\end{array}$ & $\begin{array}{l}\text { Aggressive } \\
\text { Depressive } \\
\text { Negativistic } \\
\text { Antisocial } \\
\text { Histrionic }\end{array}$ & $\begin{array}{c}0.35 \\
0.34 \\
0.22 \\
-0.16 \\
0.13\end{array}$ & $\begin{array}{l}23.92 \\
27.64 \\
7.27 \\
7.45 \\
6.53\end{array}$ & $\begin{array}{l}0.0000 \\
0.0000 \\
0.0073 \\
0.0066 \\
0.0110\end{array}$ & $\begin{array}{c}0.508 \\
p=0.000\end{array}$ \\
\hline $\begin{array}{l}\mathbf{I} \\
\mathrm{N} \\
\mathrm{T} \\
\mathrm{R}\end{array}$ & $\begin{array}{l}\text { Histrionic } \\
\text { Schizoid } \\
\text { Nareissistic } \\
\text { Antisocial }\end{array}$ & $\begin{array}{c}-0.47 \\
0.18 \\
-0.16 \\
-0.15\end{array}$ & $\begin{array}{l}46.45 \\
7.25 \\
6.93 \\
6.42\end{array}$ & $\begin{array}{l}0.0000 \\
0.0074 \\
0.0088 \\
0.0117\end{array}$ & $\begin{array}{c}0.444 \\
p=0.000\end{array}$ \\
\hline
\end{tabular}

orrelations between PSY-5 and MCMI-III Personality Disorder scales

\begin{tabular}{|c|c|c|c|c|}
\hline AGGR-r & PSYC-r & DISC-r & NEGE-r & INTR-r \\
\hline$-0,11$ & 0,43 & 0,04 & 0,39 & 0,47 \\
\hline$-0,23$ & 0,44 & 0,04 & 0,47 & 0,41 \\
\hline$-0,07$ & $\mathbf{0 , 5 2}$ & 0,09 & $\mathbf{0 , 6 3}$ & 0,27 \\
\hline$-0,20$ & 0,45 & 0,07 & $\mathbf{0 , 5 1}$ & 0,15 \\
\hline 0,37 & $-0,18$ & 0,13 & $-0,21$ & $-\mathbf{0 , 6 4}$ \\
\hline $\mathbf{0 , 6 1}$ & 0,03 & 0,35 & $-0,12$ & $-0,48$ \\
\hline 0,29 & 0,37 & $\mathbf{0 , 6 0}$ & 0,35 & $-0,12$ \\
\hline 0,36 & 0,48 & 0,44 & $\mathbf{0 , 5 6}$ & $-0,04$ \\
\hline$-0,02$ & $-0,17$ & $-0,29$ & $-0,20$ & 0,05 \\
\hline 0,15 & $\mathbf{0 , 5 7}$ & 0,28 & $\mathbf{0 , 6 4}$ & 0,11 \\
\hline$-0,07$ & $\mathbf{0 , 5 8}$ & 0,15 & $\mathbf{0 , 5 6}$ & 0,23 \\
\hline$-0,00$ & $\mathbf{0 , 6 5}$ & 0,20 & $\mathbf{0 , 5 3}$ & 0,24 \\
\hline 0,05 & $\mathbf{0 , 5 8}$ & 0,27 & $\mathbf{0 , 6 1}$ & 0,16 \\
\hline 0,18 & $\mathbf{0 , 6 1}$ & 0,23 & 0,44 & 0,07 \\
\hline
\end{tabular}

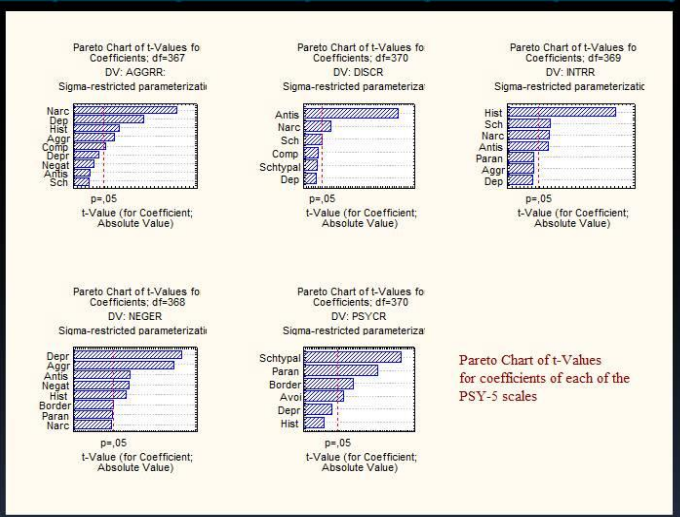

These Pareto charts shows the parameter estimates and $t$-values associated sorted by their absolute size. A vertical line will also be shown to indicate the minimum magnitude of statistically significant parameter estimates, given the current criterion of statistical significance (alpha $=0.05)$

\section{REFERENCES}

\section{CONCLUSIONS}

All PSY-5 scales are predicted by several MCMI-III PD scales with a moderate percentage of variance and its association are in line of results obtained by different authors (Wygant et al., 2006; Arnau et al., 2005; Harkness et al., 2011). This variability of personality disorders scales associated with PSY-5, make them less effective to identify a single disorder but guide toward a group of disorders.

All PSY-5 scales combine various personality disorders belonging to different clusters. It is necessary more research to examine PSY-5 scales in relation to abnormal personality using approaches other than objective 


\title{
$\because$ issid 20 ï 3 Barcelona, July $22^{\text {nd }}-25$ th
}

\section{COMPARATIVE ANALYSIS OF THE PSY-5 AND MCMI-III IN ASSESSING PERSONALITY DISORDERS}

\author{
Fusté, A., Ruiz, J. \& García, E. \\ Department of Personality, Assessment and Psychological Treatments \\ University of Barcelona
}

According to Harkness and McNulty (1994) the Personality Psychopathology-Five (PSY-5) including in the MMPI-2-RF is a dimensional model developed to conceptualize the traits underlying personality psychopathology. The present study examines the correspondence between PSY-5 scales and MCMI-III Personality Disorder (PD) scales. The current sample includes 377 clients (167 men and 210 women) from private practice settings who completed the MMPI-2-RF and MCMI-III. Besides correlation analysis, we performed several multiple regression analyses taking the PSY-5 scales as dependent variables and the MCMI-III PD scales as predictor variables to study the shared variance between both groups of scales. The analysis was performed using the stepwise method and the tolerance level was set at 0.60. The percentage of variance of each of PSY-5 scales explained by MCMI-III PD scales ranged between $40 \%$ and $50.8 \%$, and several MCMI-III PD scales were significant in predicting the PSY-5 scales. Implications of the results will be discussed.

American Psychiatric Association (APA, 2000). Diagnostic and Statistic Manual of Mental Disorders (4th ed.). Test revision. Washington, DC.

Arnau, R., Handel, R.W. and Archer, R.P. (2005). Principal components analyses of the MMPI-2 PSY-5 Scales. Assessment, 12 (2), 186-198.

Ben-Porath, Y.S \& Tellegen, A. (2008). MMPI-2-RF Minnessota Multiphasic Personality Inventory-2 Restructured Form. Minneapolis, MN: University of Minnesota Press.

Harkness, A.R., \& McNulty, J.L. (1994). The Personality Psychopathology Five (PSY5): Issue from the pages of a diagnostic manual instead of a dictionary. In S. Strack \& M. Lorr (Eds), Differentiating normal and abnormal personality (pp. 291-315). New York, NY: Springer.

Harkness, A.R., Finn, J.A., McNulty, J.L., \& Shields, S.M. (2011). The Personality Psychopathology-Five (PSY-5): Recent Constructive Replication and Assessment Literature Review. Psychological Assessment. Advance online publication. DOI: $10.1037 / \mathrm{a} 0025830$.

Wygant, W.B., Sellbom, MS., Graham, J.R. \& Schenk, P.W. (2006). Incremental validity of the MMPI-2 PSY-5 scales in assessing self-reported personality disorder criteria. Assessment, 13(2), 178-186. 